\title{
鳥ロ突起センタリングジグの改良
}

\begin{tabular}{|c|c|c|c|c|c|c|}
\hline 福岡大学医学 & 部整开 & & & & & \\
\hline 渡 & 辺 & 伸 & 彦・柴 & 田 & 陽 & 三 \\
\hline 緑 & 川 & 孝 & 二・内 & 田 & 洋 & 子 \\
\hline 江 & 本 & & 玄・緒 & 方 & 公 & 介 \\
\hline 佐藤第一病院 & & & & & & \\
\hline 伊 & 崎 & 輝 & 昌 & & & \\
\hline
\end{tabular}

\section{Improvement in Drilling Instruments for the Coracoid Process}

by

\author{
Nobuhiko Watanabe, Yozo Shibata, Koji Midorikawa, \\ Yoko Uchida, Gen Emoto and Kosuke Ogata \\ Department of Orthopaedic Surgery, School of Medicine, \\ Fukuoka University

\section{Teruaki Izaki} \\ Sato Daiiti Hospital
}

\begin{abstract}
We developed a drilling instrument (Type 1) for the coracoid process two years ago, and have been performing a modified Boytchev's procedure for patients with recurrent shoulder disloction using this instrument.

When we inserted a screw into the coracoid process using the Type 1 instrument, the axis of the screw was directed caudally toward the coracoid process. We have now developed a new drilling instrument for the coracoid process (Type 2) that is able to insert the screw correctly into the center of the coracoid process. We performed a comparative study concerned with direction of the screw for three groups. Group $1: 13$ cases had a screw inserted without intstrumentation. Group 2: 14 cases had their screw inserted using the Type 1 instrument. Grupe $3:$ Five cases had their screw inserted using the Type 2 instrument. Angles of inserted screw toward the coracoid process were compared in each group and were measured in antero-postero views, scapular outlet views and axial views by plain X-ray after the modified Boytchev procedure. The angles of Group 1 revealed a larger deviation than one of Group 1 and Group 2. The angles of Group 2 and Group 3 were less than the one of Group 1 in A-P views and Y-views. Using the improved drilling instrument for the coracoid process (Type 2), a hole can be easily made in the center of the coracoid process.

The Type 2 instrument is available for various shoulder operations, for example, Bankart's procedure, capsular shift, Dewar's procedure, Bristow's procedure and total replacement of the shoulder joint.
\end{abstract}

Key words : osteotomy (骨切り術), Boytchev’s procedure (ボイチェフ法), coracoid process (鳥口突 起)

はじめに

肩関節手術で鳥口突起を一時的に切離しスクリュー
で再固定する機会は多い. 特に当科では反復性肩関節 脱臼の手術療法にBoy chev 変法を採用しており, プ レドリリングを鳥口突起の中心に施行できる様鳥口突 
起センタリングジグを開発し，平成 4 年より臨床応用 してきた.この従来のジグ（タイプ1）は，コの字型 の先端にて鳥口突起を上下からはさみ突起中央にプレ ドリリング出来る形状をとっていた（図 1 )。しかし ドリリング時の方向性がやや不安定であるため，スク リューの先端が頭側に向かう傾向にあった．そこで今 回，ジグ先端をフック状にし，鳥口突起の後面に掛け ることで鳥口突起長軸により平行なドリリングを可能 にするジグタイプ 2 を開発した（図 2 ). 今回我々は, ジグ末使用群, タイプ 1 使用群, タイプ 2 将群でのス クリューの位置を比較検討したので報告する。

\section{対象並びに方法}

当科で平成 3 年から 6 年 7 月までに施行した Boytchev 変法計 32 肩（ジグ未使用 13 肩，タイプ 1 使用 14 肩，タイプ 2 使用 5 肩）に対し，術後レント ゲンの前後，軸射，肩甲骨Y撮影にて刺入されたスク リューの鳥口突起軸に対する偏位角度を測定した（図 3 ).

刺入されたスクリューの偏位角度は鳥口突起長軸と 為す角度で測定した. 前後像では頭側にスクリューが 向くものを, 軸射像では内則を, 肩甲骨 Y 撮影では頭 側に向くものを偏位角度のプラスとした。

\section{結果}

1. 前後像の結果
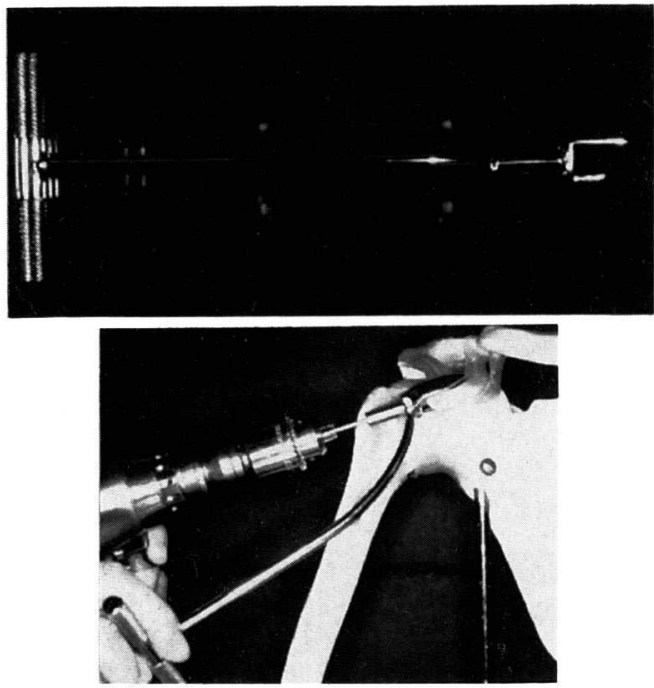

図1 センタリングジグタイプ 1
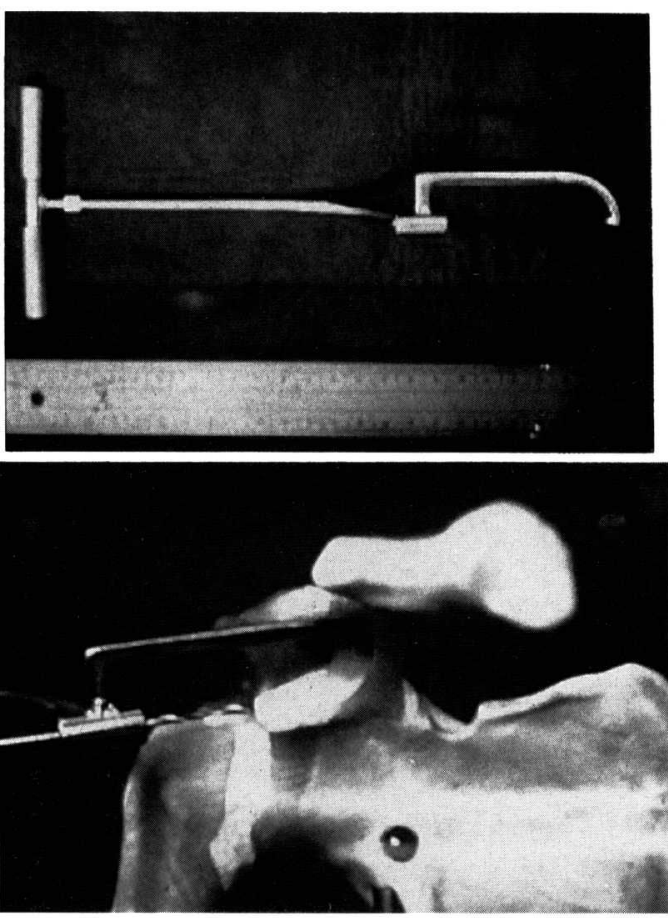

図 2 センタリングジグタイプ 2

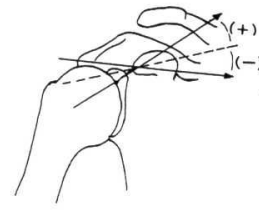

前後像

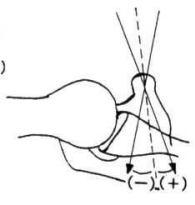

軸射像

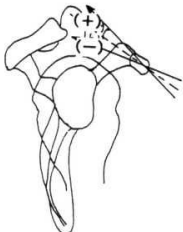

肩甲骨Y撮影像
図 3 スクリュー偏位度の測定法

ジグ未使用群ではスクリューは平均 25 度と，頭側 に向かう傾向が強かった。ジグタイプ 1 使用群は平均 16.6 度と末使用群より低值を示したが，有意差はなかっ た.タイプ 2 使用群では 4.8 度と末使用群, タイプ 1 使用群に比しそれぞれ有意に頭側偏位度が小さく，鳥 口突起軸に平行に刺入されていた（表 1 ）。

2 . 軸射像の結果

未使用群，タイプ 1 および 2 使用群の間に有意差は 認められず，かつ何れも鳥口突起にほほ平行に刺入さ れていた（表 2 )。

3. 肩甲骨 $\mathrm{Y}$ 撮影の結果

ジグ未使用群に比し，使用群の方が有意に偏位度は 


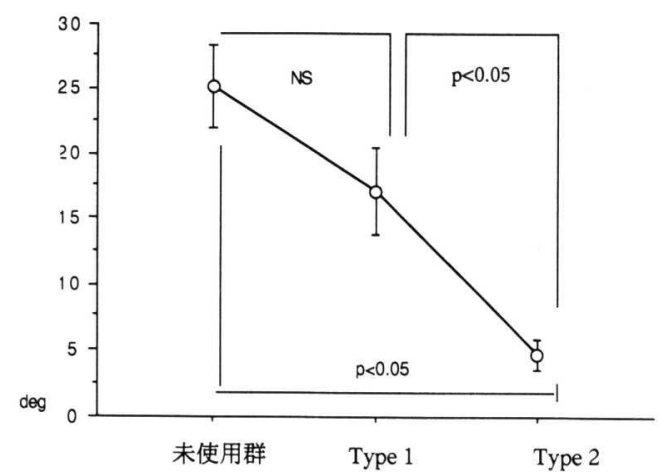

表 1 前後像結果

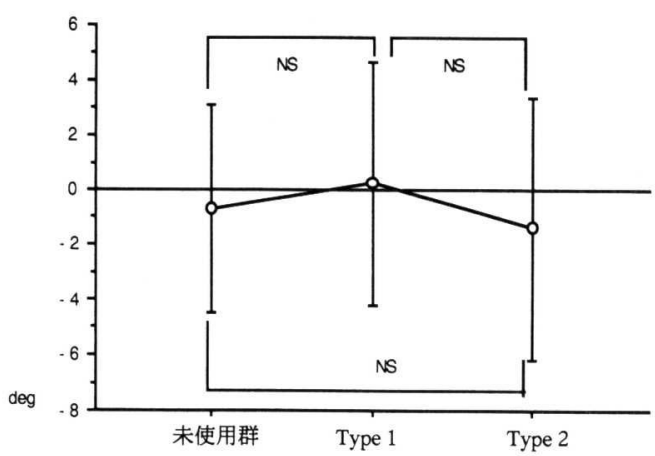

表 2 軸射像結果

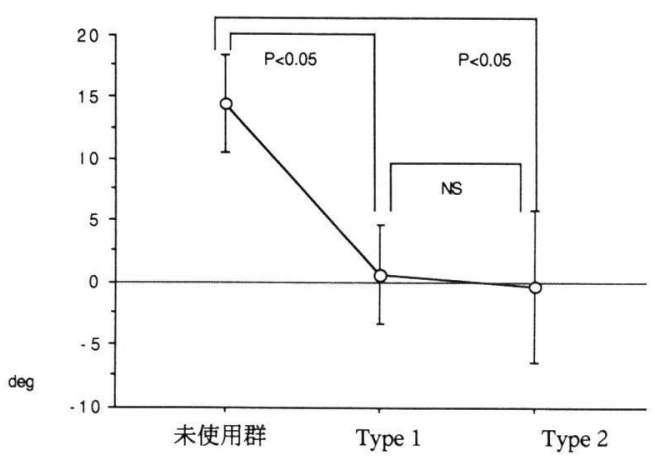

表 3 肩甲骨Y撮影結果

少なかった. タイプ 1 と 2 の使用群の間では有意差は なく, 両者とも鳥口突起にほほ平行に刺入されていた (表 3 ).

\section{症 例 供 覧}

症例 $1: 17$ 才男性ジグ末使用例で, 鳥口突起に偏 在性にブレドリリングされたため鳥口突起が 3 つの骨

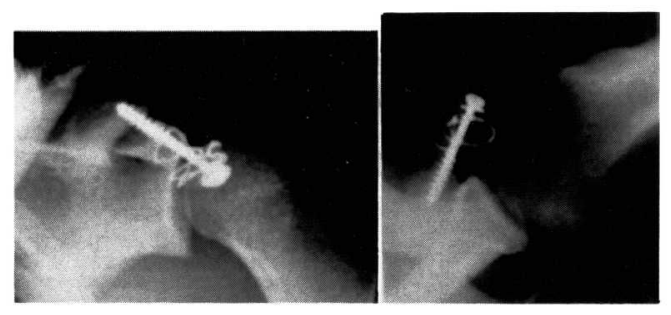

図417才男性, 鳥口突起骨折が認められた（ジグ未 使用)

片に割れ，wireringを追加した症例である（図 4 ）。

症例 $2: 20$ 才男性ジグタイプ 1 使用例で, 正面像 でプラス 30 度, 軸射でマイナス 15 度, 肩甲骨 $\mathrm{Y}$ 撮影 でマイナス 15 度のスクリュー偏位が認められる（図 5 ).

症例 $3: 26$ 才男性ジグタイプ 2 使用例で, 正面像 でプラス 5 度, 軸射でプラス 5 度, Y 撮影ではマイナ ス 5 度, 正面像におけるスクリューの頭側偏位の低下 が認められる（図6).

\section{考察}

内田らの報告では, Boytchev 変法 120 肩（全てジ グ未使用）中, 鳥口突起先端の骨折が 5 肩 ( $4 \%$ ), 偏在刺入によるスクリューの突出が 4 肩 (3.3\%) に 認められ, これは鳥口突起が小胸筋, 合同腱, 烏口肩 峰䩲帯に包まれており, その真の方向が術中確認し難 いことが挙げられる ${ }^{5)}$. Boytchev 変法の手術効果を 期待するためには確実な鳥口突起の再固定が重要であ り, 我々は鳥口突起センタリングジグタイプ 1 を作成 し平成 4 年から 6 年 4 月まで臨床応用してきた.この 間のBoytchev 変法施行例 14 肩に鳥口突起骨折やス クリュー突出は認められなかったが, 前後像で見ると 頭側に向けて刺入される傾向にあった. そこで今回, 頭側偏位を改善させる目的でジグの改良を行った. 改 良点は, ジグの先端にフックを設け, ドリルガイドの 中心がこのフックに向かうように設計した. 内田の報 告によると鳥口突起上下の厚みは $8 \mathrm{~mm}$ から $14 \mathrm{~mm}$ までの variationがあるが, フック状のジグ先端を鳥 口突起後面に掛けることで, 鳥口突起の厚さの variation に左右されずに中心部へドリリングできる ようになった，臨床応用の結果，これまで使用してい た螺子の長さは平均 $35 \mathrm{~mm}$ であったが， ジグ改良後 は平均 $40 \mathrm{~mm}$ と長くなりそれだけ鳥口突起先端から 


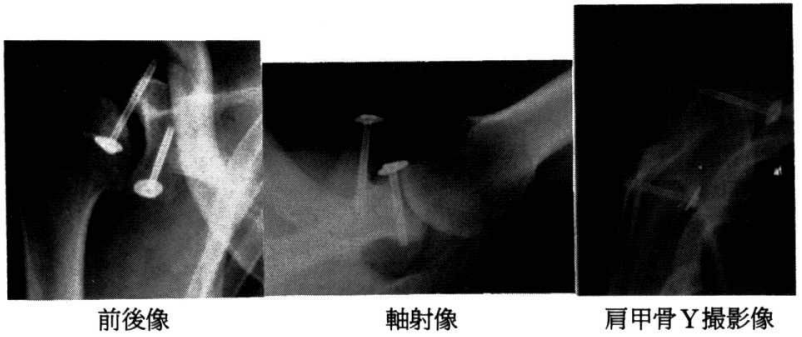

図 520 才男性, ジグタイプ 1 使用例

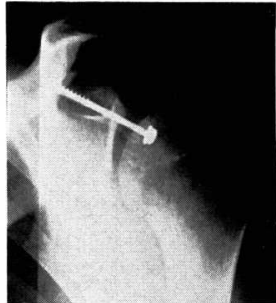

前後像

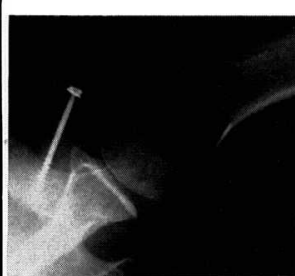

軸射像

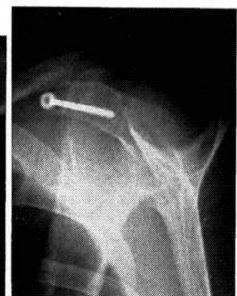

肩甲骨Y撮影像

図626才男性，ジグタイプ 2 使用例

突起後方の屈曲部分までの最大長にドリリングが可能 となった。単に使用スクリューが長くなったというこ とではなく，長いスクリューを使用できるということ は, それだけ烏口突起の中心にドリリングできた結果 と考える。症例は 5 肩とまだ少ないが, 頭側偏位は減 少しほぼ満足できる結果を得ている，また烏口突起を 切離し原位置もしくは他の部位に固定する必要のある 手術として Bristow法 ${ }^{1)}$, Dewar法 ${ }^{2)}$, capsular shift 法 $^{3)}$, 人工肩関節置換術 ${ }^{4)}$ などがあるが, これらの手 術に際しても一助となる器具と考える.

\section{ま と め}

1. 改良型の烏口突起センタリングジグタイプ 2 を 作成し, 烏口突起内部でのスクリューの偏位度をジグ 末使用群, タイプ 1 使用群, タイプ 2 使用群で比較検 討した。

2.未使用群ではスクリューのばらつきは大きかっ た.

3.タイプ1では未使用群に比し, 肩甲骨Y撮影に おける偏位度が小さかった。

4.タイプ 2 では未使用群に比し, 前後像と肩甲骨
$\mathrm{Y}$ 撮影で偏位度が有意に小さかった，又，タイプ 1 に 比しても前後像で有意に偏位度が小さかった。

5 . 改良型の鳥口突起センタリングジグタイプ 2 は, タイプ 1 ジグに比して鳥口突起のより中心部にスクリュー を刺入することができた。

\section{参 考 文 献}

1) Helfet, A. J. : Coracoid transplantation for recurring dislocation of the shoulder. J Bone Joint Surg, 40-B : 198-202, 1958.

2) Dewar, F. P. : The treatment of chronic acromilclavicular dislocation. J Bone Joint Surg, 47-B : 32 35, 1965.

3) Neer, C. S. : Replacement arthroplasty for glenohumeral osteoarthritis. J Boen Joint Surg, 56-A : 113, 1974.

4) Neer, C. S. : Inferior capsular shift for involuntary inferior and multidirectional instability of the shoulder ; preliminary report. J Bone Joint Surg, 62-A : 897-908, 1980.

5）内田洋子：鳥口突起センタリングジグの開発. 整形・ 災害外科, $42: 262-264,1993$. 